\title{
Study on Evaluation Index System of Economic Level of Low-carbon City in Guiyang
}

\author{
Bingsheng Guo ${ }^{1,2}$ \\ ${ }^{1}$ School of Economics, Wuhan University of Technology, Wuhan, 430070 China \\ ${ }^{2}$ The CPC Liupanshui Municipal Committee of the Party School, Liupanshui, 553000 China \\ Email: 254169190@qq.com
}

Key words: Low-carbon City; Evaluation Index System; DPSIR Mode

Abstract: The global climate is undergoing a significant change with global warming. The cause of this change is greenhouse gas emissions by carbon dioxide. This article embarks from the challenges faced by construction of low-carbon city in Guiyang, using DPSIR model, from five aspects, including driving, pressure, status, impact and response, build a set of evaluation index system composed of 23 indicators. With this index system, the typical low-carbon pilot cities of Guiyang was estimated. Results show that the economic level of Guiyang city in 2010-2014 is on the rise.

\section{Introduction}

Intergovernmental Panel on Climate Change (IPCC) studied found carbon dioxide emissions mainly come from urban areas which is about $80 \%$ of the total global carbon emissions ${ }^{[1]}$. Therefore, the construction of "low-carbon city" has important significance to curb global warming. Therefore, developed regions and Guiyang adopt the same low-carbon urban economic evaluation criteria are not reasonable. Guiyang needs to build a set of low-carbon urban economic evaluation index system which is suitable for their own standards.

Shwayri s. t. (2013) believed that the carbon emissions per person should be used to assess the level of low-carbon cities, not total carbon emissions ${ }^{[3]}$.Edwin h. w. (2013) uses the proportion of clean energy accounted for primary energy to evaluate economic level of low-carbon cities in the 66 citiesl $^{[4]}$.Dai Yixin (2009), Tsinghua University, believed that the development level of low-carbon cities can be seen from the intensity of carbon emissions ${ }^{[5]}$.

\section{Evaluation Index System of Low-carbon Urban Economy in Guiyang}

\section{Overall Design Ideas of Index System}

Low-carbon urban economy has encountered many challenges in Guiyang. During city high-speed growth, the "driving force" of social production and consumption caused a huge "pressure" to city low carbonization, change the "state" of greenhouse gas (GHG) emissions and energy consumption, impact urban air quality and climate temperature. So government agencies such as decision-making departments and the public have to take a series of measures to ensure low-carbon development. The DPSIR model can systematically describe the above process, provide a better idea for the design of low-carbon city economic evaluation index system in Guiyang. 


\section{Determination of Index System}

According to design idea of index system and the principle of index selection, we determined the low-carbon city economic level evaluation index system in Guiyang as shown in Table 1, this index system contains twelve concrete indexes.

Table 1 Evaluation Index System of Economic Level in Guiyang Low-carbon City

\begin{tabular}{|c|c|c|c|c|}
\hline $\begin{array}{l}\text { Targ } \\
\text { et } \\
\text { Laye } \\
r\end{array}$ & $\begin{array}{l}\text { Criteri } \\
\text { on } \\
\text { Layer }\end{array}$ & Factor Layer & Index layer & Index Unit \\
\hline \multirow{12}{*}{$\begin{array}{c}\text { Low } \\
\text { carbo } \\
n \\
\text { Urba } \\
n \\
\text { Econ } \\
\text { omic } \\
\text { Eval } \\
\text { uatio } \\
n \\
\text { index }\end{array}$} & \multirow{2}{*}{$\begin{array}{l}\text { Drivin } \\
\mathrm{g}\end{array}$} & \multirow{2}{*}{$\begin{array}{l}\text { Production } \\
\text { Driving }\end{array}$} & Economic growth rate $\left(D_{1}\right)$ & $\%$ \\
\hline & & & Per capita GDP $\left(\mathrm{D}_{2}\right)$ & $\begin{array}{l}\text { Yuan / } \\
\text { person }\end{array}$ \\
\hline & \multirow{6}{*}{$\begin{array}{l}\text { Pressu } \\
\text { re }\end{array}$} & \multirow{2}{*}{$\begin{array}{l}\text { Energy } \\
\text { consumption } \\
\text { pressure }\end{array}$} & Energy intensity $\left(P_{1}\right)$ & $\begin{array}{c}\text { Tons of } \\
\text { standard } \\
\text { coal / } \\
\text { million }\end{array}$ \\
\hline & & & $\begin{array}{l}\text { Unit energy consumption of industrial } \\
\text { production }\left(\mathrm{P}_{2}\right)\end{array}$ & $\begin{array}{l}\text { Tons of } \\
\text { standard } \\
\text { coal / } \\
\text { million }\end{array}$ \\
\hline & & \multirow{4}{*}{$\begin{array}{l}\text { Greenhouse } \\
\text { gas } \\
\text { emissions }\end{array}$} & Per capita carbon emissions $\left(\mathrm{P}_{3}\right)$ & $\begin{array}{c}\text { Tons / } \\
\text { person }\end{array}$ \\
\hline & & & Per land carbon emissions $\left(\mathrm{P}_{4}\right)$ & Tons $/ \mathrm{km}^{2}$ \\
\hline & & & $\begin{array}{l}\text { Per capita emissions of sulfur dioxide } \\
\qquad\left(\mathrm{P}_{5}\right)\end{array}$ & $\begin{array}{c}\text { Tons / } \\
\text { person }\end{array}$ \\
\hline & & & $\begin{array}{l}\text { Per land emissions of sulfur dioxide } \\
\qquad\left(\mathrm{P}_{6}\right)\end{array}$ & Tons $/ \mathrm{km}^{2}$ \\
\hline & \multirow{4}{*}{$\begin{array}{c}\text { Respo } \\
\text { nse }\end{array}$} & \multirow[b]{2}{*}{ Government } & $\begin{array}{l}\text { Environmental protection investment } \\
\text { accounted for fiscal expenditure }\left(\mathrm{R}_{1}\right)\end{array}$ & $\%$ \\
\hline & & & $\begin{array}{l}\text { monitoring coverage of Enterprise } \\
\text { energy saving and emission reduction } \\
\left(\mathrm{R}_{2}\right)\end{array}$ & $\%$ \\
\hline & & \multirow{2}{*}{ masses } & $\begin{array}{l}\text { share ratio of household using solar, } \\
\text { geothermal or biogas energy }\left(\mathrm{R}_{3}\right)\end{array}$ & $\%$ \\
\hline & & & $\begin{array}{l}\text { use rate of household energy saving } \\
\text { appliances }\left(\mathrm{R}_{4}\right)\end{array}$ & $\%$ \\
\hline
\end{tabular}

\section{Application of Low-carbon Urban Economic Evaluation Index System in Guiyang}

\section{Data Collection and Standardization}

The original data come from "Guiyang Statistical Yearbook," "Guizhou Statistical Yearbook",

" China urban statistical yearbook ", "China Meteorological Statistical Yearbook," and " China 
Environmental Statistics Yearbook".

\section{Calculation Formula of Index Weight}

Entropy method is a method that objectively determine the weights based index value, especially for the Multiple Indicator Index system synthesized by multiple indicator ${ }^{[6]}$. In this paper, we calculate the index weight using entropy method.

$f_{j} 、 p_{j} 、 u_{j}$ respectively is weight value, entropy, index value of $j$ index. $\mathrm{K}$ is index number. $\mathrm{M}$ is different years (set 2010 for the first years, namely $m=1$, by analogy in the future), then,

$$
\begin{gathered}
f_{j}=\frac{1-p_{j}}{\sum_{j=1}^{k}\left(1-p_{j}\right)} \\
p_{j}=-k \sum_{i=1}^{m}\left[\left(u_{i j} / \sum_{i=1}^{m} u_{i j}\right) \cdot \ln \left(u_{i j} / \sum_{i=1}^{m} u_{i j}\right)\right]
\end{gathered}
$$

Equation (1) and (2) are index weight calculation formula.

\section{Evaluation Results}

The data are substituted into weighted average formula (equation (3)), when $\mathrm{g}=1$ and $\mathrm{h}=23$, we can obtain evaluation index in 2010-2014 years.

$$
\text { Assessment Results }=\sum_{j=g}^{h}\left(f_{i j} \cdot u_{i j}\right) \quad i=1,2,3,4,5
$$

When $\mathrm{g}=1$ and $\mathrm{h}=5, \mathrm{~g}=6$ and $\mathrm{h}=11, \mathrm{~g}=12$ and $\mathrm{h}=15, \mathrm{~g}=16$ and $\mathrm{h}=19, \mathrm{~g}=20$ and $\mathrm{h}=23$, the values of driving, pressure, state, influence and response are calculated respectively.

\section{Research Conclusion and Revelation}

The values of driving, pressure, state, influence, response and evaluation index of 2010-2014 years show that low-carbon city economy in Guiyang has the following characteristics:

(1) Low-carbon urban economic level has a rising trend in general. Evaluation index respectively is $0.797,0.746,1.21,0.988,1.365$ in $2010-2014$ years. The value is basically in constant increase. The higher value, the greater low-carbon city economic level. In recent years, Guiyang has been in the forefront of social economic development, and industrial and energy structure optimization is also fruitful. Its urban low-carbon construction is obvious, which has become a success stories of low-carbon city economic.

(2) Social and economic driving force has been increasing year by year. Driving force from 0.424 in 2010 year rised to 0.588 in 2014 year. The social production and consumption are driving the rapid development of city. The data of "China Statistical Yearbook in 2015 year " and "statistical yearbook of Guizhou 2015" show that, from 2010 to 2014, Guiyang annual GDP growth rate ranked second in the country, and "global urban competitiveness report (2014-2015)" released by the Chinese Academy of Social Sciences, also shows upgrade speed of regional comprehensive competitiveness is the fourth. "Guiyang speed" is conspicuous, effectively pulling the economy of low-carbon city.

(3) The pressure of urban low-carbonization is increasing. Pressure increased from 0.308 in 
2010 year to 0.466 in 2014 year, suggesting that the growing pressure caused by greenhouse gas emissions of economic growth, urban population increase, consumption of coal and electric are prominent. Per capita carbon emissions is 7.52 tons in 2010 year, that number in 2012 year and 2014 year has respectively increase to 10.27 and 14.56 tons, brought huge pressure on the path of low-carbon for Guiyang.

At present, Guiyang has the characteristics of high growth (high driving force). The pressures of urban population, resources and environmental will become more and more. We cannot at the expense of economic development and people's quality of life to achieve "low-carbon". Therefore we must consider that in the form of "carbon neutral" to ensure low-carbon city economy. Government can focus on supporting a number of carbon emissions trading market in Guiyang, in these markets, vigorously promote green finance, green credit and policy tilt, encourage enterprises to actively participate in carbon emissions offset mechanism. Government should also develop measures to protect forests, grasslands, wetlands and other carbon sinks which can fully play the role of carbon absorption.

\section{Reference}

[1] Pachauri R. K., Reisinger A. Climate change 2007: synthesis report[R]. Geneva, Switzerland : Intergovernmental Panel on Climate Change,2007:1-5.

[2] World Resources Institute. Climate analysis indicators tool[R]. New York , U. S. A. : WRI,2010:3-4.

[3] Shwayri S. T. A model Korean ubiquitous eco-city? the politics of making songdo[J]. Journal of Urban Technology, 2013,20(1): 39-55.

[4] Edwin H. W., Lennon H. T., Esther H. K. Y. Current research on low carbon cities and institutional reponses[J]. Habitat International, 2013, 37(1): 1-3.

[5] Dai Yixin. Study on the concept evolution and measurement of low-carbon city development [J]. Modern urban research,2009, (11) : 7-12.

[6] Rory S., Andy G., Webber P. Funding low carbon cities: local perspectives on opportunities and risks[J]. Climate Policy, 2013,13(4): 514-529. 